\title{
ASSESSMENT OF POULTRY WASTE MANAGEMENT IN TRISHAL UPAZILA, MYMENSINGH
}

\section{Md. Shahadat Hossen ${ }^{1 *}$, Ziaul Hoque ${ }^{2}$ and Begum Samsun Nahar ${ }^{3}$}

${ }^{1}$ Department of Environmental Science, Bangladesh Agricultural University, Mymensingh; ${ }^{2}$ MS Student, Department of Environmental Science, Bangladesh Agricultural University, Mymensingh; ${ }^{3}$ Centre for Environmental Studies, Bangladesh Agricultural University, Mymensingh-2202, Bangladesh

*Corresponding author: Md. Shahadat Hossen; E-mail: mshossen@bau.edu.bd

\section{ARTICLE INFO}

ABSTRACT

\begin{abstract}
Received
12.08 .2015

Accepted

26.08.2015

Online

03.09.2015

Key words

Poultry waste

Management

Litter

Biogas

Composting

A study was conducted to assess the present status of poultry waste management by poultry farmers in Trishalupazila of Mymensingh district, Bangladesh during July to November 2013. A structured, pre-tested questionnaire was used for collecting data. The highest $52 \%$ respondents were involved in layer farming and majority of the respondents did not use any litter materials where $36 \%$ and $12 \%$ used rice husk and sawdust respectively as litter. The availability of storage and treatment facilities was in $24 \%$ farms but their storage system was uncovered. Fifty per cent of the farmers sold their litter while some other used as fish feed, soil amendment and for biogas production. Only $16 \%$ farmers faced diseases related to poultry waste and the rest $(84 \%)$ never faced any disease. It was noticed that $54 \%$ farmers faced environmental problems and $46 \%$ were unconcerned about environmental problem. They considered odor, flies and mosquitoes and leaching as environmental problem. Only $24 \%$ farmer mentioned financial problem as barrier of poultry waste management and majority claimed about unconsciousness. It is concluded that poultry waste management by farmers in the study area is inefficient, implying inadequate awareness of the potential negative impact of poor handling of poultry wastes. More extensive work is required to trainup the poultry farmer for proper handling and utilization of poultry wastes.
\end{abstract}

To cite this article: MS Hossen, Z Hoque and BS Nahar, 2015. Assessment of poultry waste management in Trishal Upazila, Mymensingh. Res. Agric. Livest. Fish. 2 (2): 293-300.

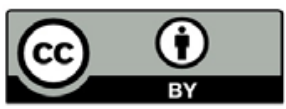

This is an open access article licensed under the terms of the Creative Commons Attribution 4.0 International License

www.agroaid-bd.org/ralf, E-mail: editor.ralf@gmail.com 


\section{INTRODUCTION}

According to the Environmental protection act 1990, the waste is a wide ranging term encompassing most unwanted materials. The term poultry wastes refers to poultry excreta, bedding materials, feather and other debris normally generated in the poultry farms at the time of waste handling operations. The production of poultry results in some accessory output: hatchery wastes, manure (bird excrement), litter (bedding materials), and on-farm mortalities. The processing of poultry results in additional waste materials, including offal (feathers, entrails and organs of slaughtered birds), processing wastewater and bio-solids. Commercial poultry industry is growing rapidly in Bangladesh and annual growth rate of chicken population is 5.3 percent (GoB, 2010). Presently poultry, mainly chicken (broiler and layer) industry is a rapid rising and prospective sector in Bangladesh. There are about 1, 50,000 commercial poultry farms (broiler and layer farms) and near about 130 Parent stock farms in Bangladesh (ICDDRB, 2008). Poultry wastes are produced as a result of the normal everyday processes of the poultry industry. The weight of fresh poultry manure is estimated as $15 \%$ of the total dry matter intake. It contains about $28-30 \%$ crude protein in which $36-50 \%$ is true protein (Bhattacharya and Taylor, 1975). Most of the by-products contain organic and inorganic nutrients that are of biological value if managed and recycled properly, regardless of flock size. However, they also give rise to potential environmental and human health concerns as the sources of elements, compounds, vectors for insects and vermin, and pathogenic microorganisms.

About 3079 metric tons poultry manures are produced daily from a total of 42 million chickens in Bangladesh (Waste concern, 2005). The large quantities of poultry waste production pose serious socioeconomic problems, the most prominent of which is the protection of our environment and our environmental resources particularly polluting the surface water, groundwater and air environment at high level (Alabadan et al. 2009; FAO, 2008; Dahal, 1993). Poultry manure also contains pathogens which may potentially affect soil and water resources and can remain viable in the environment for long periods of time (Bowman et al., 2000). Continuous dumping can lead to serious health concerns (Akinbile, 2012). It is therefore necessary to timely dispose of wastes in an efficient method which is an important management tool for raising healthy and profitable poultry industries. Therefore, the present research work was conducted to identify the types and amount of wastes generated in the poultry farms in TrishalUpazila and environmental consideration of poultry waste management.

\section{MATERIALS AND METHODS}

\section{Study area}

TrishalUpazila with an area of $338.98 \mathrm{sq} \mathrm{km}$, located in between $24^{\circ} 28^{\prime}$ and $24^{\circ} 41^{\prime}$ north latitudes and in between $90^{\circ} 18^{\prime}$ and $90^{\circ} 32^{\prime}$ east longitudes (Banglapedia, 2013). The population constituted 180 poultry farms from where 50 farms were randomly selected as sample for this study.

\section{Data collection procedure}

In order to collect relevant information, a semi-structured questionnaire was prepared to collect data. The questionnaire was carefully designed keeping the objectives of the study in view. The schedule was translated into Bengali (Native language) to facilitate data collection. The questionnaire was pre-tested with selected Livestock Officers at the Trishal Upazila so as to ensure that the questionnaire did not contain any ambiguity and that it could be easily understood and completed by respondent. Data were collected through personal interview during July to September 2013.

Information was obtained on litter management knowledge, barrier of waste management, disease related waste, about environmental problem, about storage and treatment facilities, utilization of waste. There were also some questions to evaluate the knowledge level about environment and waste management. Additional information was collected through personal communication during farm visits. Collected data were analyzed using simple statistical techniques for calculating frequencies and percentages and the results are presented in tables and figures. 


\section{RESULTS AND DISCUSSION}

\section{Type of farm and wastes}

Three types of farm were found in this study area. Those were broiler, layer and cockerel farms. In this study, 52\% respondents were involved in layer farming, $40 \%$ in broiler and $8 \%$ in cockerel farming (Fig. 1). Layer hens produced high quality of dropping wastes, because laying hens are usually reared in cages.

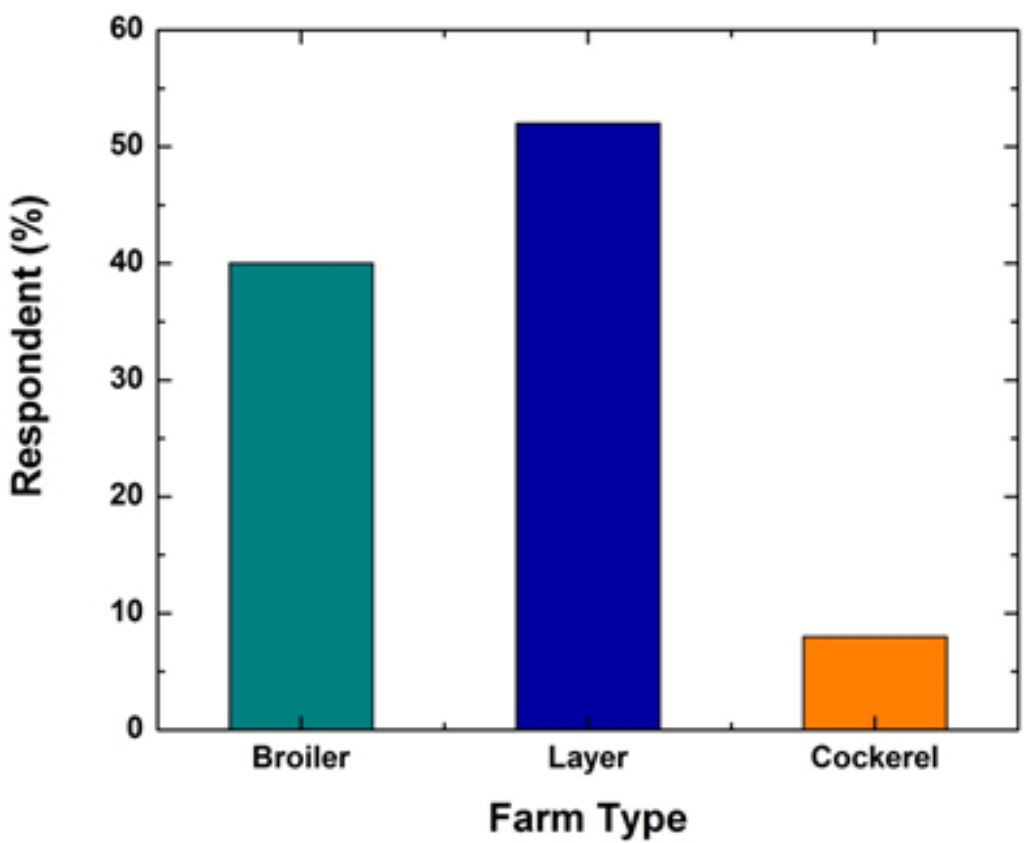

Figure 1. Number (\%) of farmers engaged in different farm types in the study area

The wastes obtained in the study area were mainly solid in nature and composed of excreta, feed, feathers, and bedding materials. The distribution of the different litter materials are presented in Figure 2. About 45\% farm owner did not use any litter materials as majority of our studied farm was layer type and grown in cage houses and least $7 \%$ used other than sawdust and rice husk. For broiler houses they prefer rice husk (36\%) to sawdust $(12 \%)$ because rice husk is more available than sawdust. Litter quality will affect the environmental hygiene of the birds by influencing dust levels, air humidity and ammonia levels. Litter materials with a high water holding capacity, such as sawdust, are believed to result in better litter quality than litter materials with poorer absorption capacity such as rice husk. According to Adeyemi and Malomo (2014) wood shaving is the most popularly used (44\%) litter material followed by sawdust used by $11 \%$ of respondents while crushed corn cobs and grasses were used by 3.29 and $6.59 \%$ of the respondents while $18.68 \%$ of the respondents did not use any litter materials in Nigeria.

The quantity of litter is directly linked to the number of birds reared. On the basis of quantity of litter, farms were classified into four categories. The interval between two categories was 100 . About 26 percent farms produced up to $100 \mathrm{~kg}$ litter per day while 54 percent farms produced 101-200 kg litter per day. Only 6 percent farms produced more than $300 \mathrm{~kg}$ per day while 14 percent farms had a range of 201-300 $\mathrm{kg}$ per day (Table 1). 


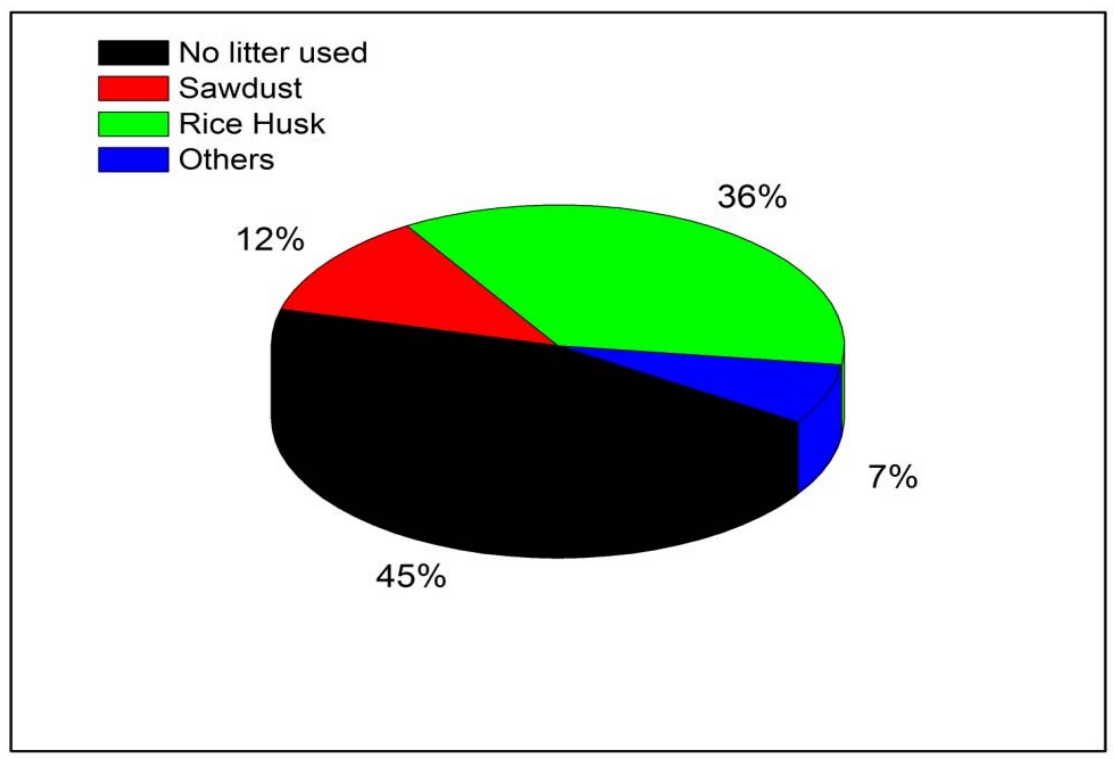

Figure 2. Types of bedding or litter material used in poultry farms

Table 1. Quantity of litter production in farms in the study area

\begin{tabular}{lcc}
\hline Quantity of litter (in kg) & \multicolumn{2}{c}{ Respondents } \\
\cline { 2 - 3 } & & Number \\
Up to 100 & 13 & 26 \\
101 to 200 & 27 & 54 \\
201 to 300 & 07 & 14 \\
$>300$ & 03 & 06 \\
\hline Total & 50 & 100 \\
\hline
\end{tabular}

\section{Waste management}

Sustainable waste management system requires storage and treatment facilities. This study shows, 24 percent farms had these facilities partially or fully and the rest 76 percent farms had no storage facility (Table 2). The storage capacity of those 12 farms undergoes three categories. Nine farms had capacity of less than $200 \mathrm{~kg}$. Two farms had capacity ranged between 200 to $500 \mathrm{~kg}$ while one farm had a capacity of more than $500 \mathrm{~kg}$ and the percentages were 75.0, 16.7 and 8.3, respectively (Table 2). In another study, it was found that among farmers, $83.3 \%$ store in pit, $8.3 \%$ on the roadside and $8.3 \%$ in the bio-gas plant (Amin et al., 2009). Proper storage of poultry litter maintain litter quality for further use and prevent contamination of surface waters on poultry farms (Dan et al., 2009).

For the answer of cover of storage tank and monitoring facilities of waste disposal system, it was found that every farm had no cover of storage tank and monitoring facilities of waste disposal system (Table 2). Storage tank means that is covered using plastic sheets anchored to the earth or other devices to protect against rain and atmospheric losses. Due to uncovered storage tank, litter washes out with rain water and enhanced environmental pollutions. Amin et al. (2009) reported that $90 \%$ of storage systems were uncovered in poultry industries. 
Table 2. Storage and treatment facilities of poultry waste in the poultry farms of the study area

\begin{tabular}{|c|c|c|}
\hline \multirow[t]{2}{*}{ Storage and treatment facilities } & \multicolumn{2}{|c|}{ Respondents } \\
\hline & Number & Percent \\
\hline Available & 12 & 24 \\
\hline \multirow[t]{2}{*}{ Unavailable } & 38 & 76 \\
\hline & \multicolumn{2}{|c|}{ Category of storage capacity $(\mathrm{kg})$} \\
\hline Less than 200 & 09 & 75 \\
\hline $200-500$ & 02 & 16.7 \\
\hline \multirow[t]{2}{*}{ More than 500} & 01 & 8.3 \\
\hline & \multicolumn{2}{|c|}{ Availability of cover of storage tank and monitoring facilities } \\
\hline Available & 00 & 00 \\
\hline Unavailable & 50 & 100 \\
\hline \multicolumn{3}{|c|}{$\begin{array}{l}\text { Waste utilization } \\
\text { Proper management and utilization of poultry wastes pose little environmental threat. About } 50 \% \text { of the } \\
\text { poultry farm owner sold their excreta and litter to others where } 20 \text { percent of farm utilized } \\
\text { for community based biogas production. About } 16 \% \text { used their excreta and litter in the crop } \\
\text { field as soil amendment. Very few percent of farms used for fish culture and household } \\
\text { composting. According to Sarker et al. (2009) among the small farm owners } 20 \% \text { farmers } \\
\text { could not use their poultry litter for any particular work, } 40 \% \text { of them sold their poultry } \\
\text { litter in the market, } 30 \% \text { of them used their poultry litter for crop production and, } 10 \% \text { of } \\
\text { them used their poultry litter for fish culture. About } 50 \% \text { of the medium farm owners used } \\
\text { their litter for fish culture and all the large farm owners sold their litter after a particular } \\
\text { time. }\end{array}$} \\
\hline
\end{tabular}

Table 3. Methods of poultry waste utilization

\begin{tabular}{lcc}
\hline Using type of poultry waste & \multicolumn{2}{c}{ Respondents } \\
\cline { 2 - 3 } & Number & Percent \\
\hline Biogas production & 10 & 20 \\
Household Composting & 4 & 8 \\
Used in crop cultivation & 8 & 16 \\
Used in Fish culture & 3 & 6 \\
Sell to others & 25 & 50 \\
Others & 5 & 10 \\
\hline Total & 50 & 100 \\
\hline
\end{tabular}

Health and environmental effects of poultry waste

Poultry litter may contain human and animal pathogens, so good hygiene has to be practiced when handling poultry waste. Farmers were questioned about their health problems related to poultry waste in answer 16\% farmer responded that they faced disease outbreaks and the rest $84 \%$ farmers reported that they never faced any disease related to waste. Among the farmers who faced disease, five farmers suffered from infection in their leg, two of them suffered from physical weakness and the rest one suffered both infection and gastrological problem (Table 4). Ammonia emissions from poultry waste can have multiple health hazards including nasal irritation and cough for both human and animal (Evans and Woolf, 2013). 
The proximity of many poultry farms to residential households has often raised a lot of concerns on human and environment. In the study area, $54 \%$ farmers considered poultry waste as an agent which has impact on environmental. They also faced some environmental problems. The rest $46 \%$ farmer's opinion was that they never faced any environmental problems.

Table 4. Diseases faced by farmer in the study area

\begin{tabular}{lcc}
\hline Name of disease & Respondents & \\
\cline { 2 - 3 } & Number & Percent \\
\hline Infection & 05 & 62.5 \\
Physical weakness & 02 & 25.0 \\
Infection and gastrological problem & 01 & 12.5 \\
\hline Total & 08 & 100 \\
\hline
\end{tabular}

The above 54 percent farmer faced several environmental problems. The highest 74.1 percent of them (54\% farmer) faced odor as well as flies and mosquitoes and the second highest 14.8 percent of the farmers faced flies and mosquitoes. Leaching of wastes and problems with flies and mosquitoes faced by 3.7 percent farmers and other 3.7 percent faced odor only while odor as well as flies and mosquitoes problems faced by 3.7 percent farmers (Figure 3 ). Waste created environmental problem in the forms of bad odor, water contamination, unwanted insects/vermin breeding, over fertilization, indoor air pollution (Waste concern, 2005). About $65.0 \%$ respondents claimed that the droppings do not cause environmental pollution, while $35.0 \%$ gave opinion in the favor of environmental pollution (Amin et al., 2012). Hossain and Ali (2009) and Griffiths (2004) reported that faulty use of droppings can cause environmental pollution. Poultry production activities enhance environmental pollution of air, water and emission of foul odour which causes huge discomfort to both the human and animal lives (Anosike, 2007).

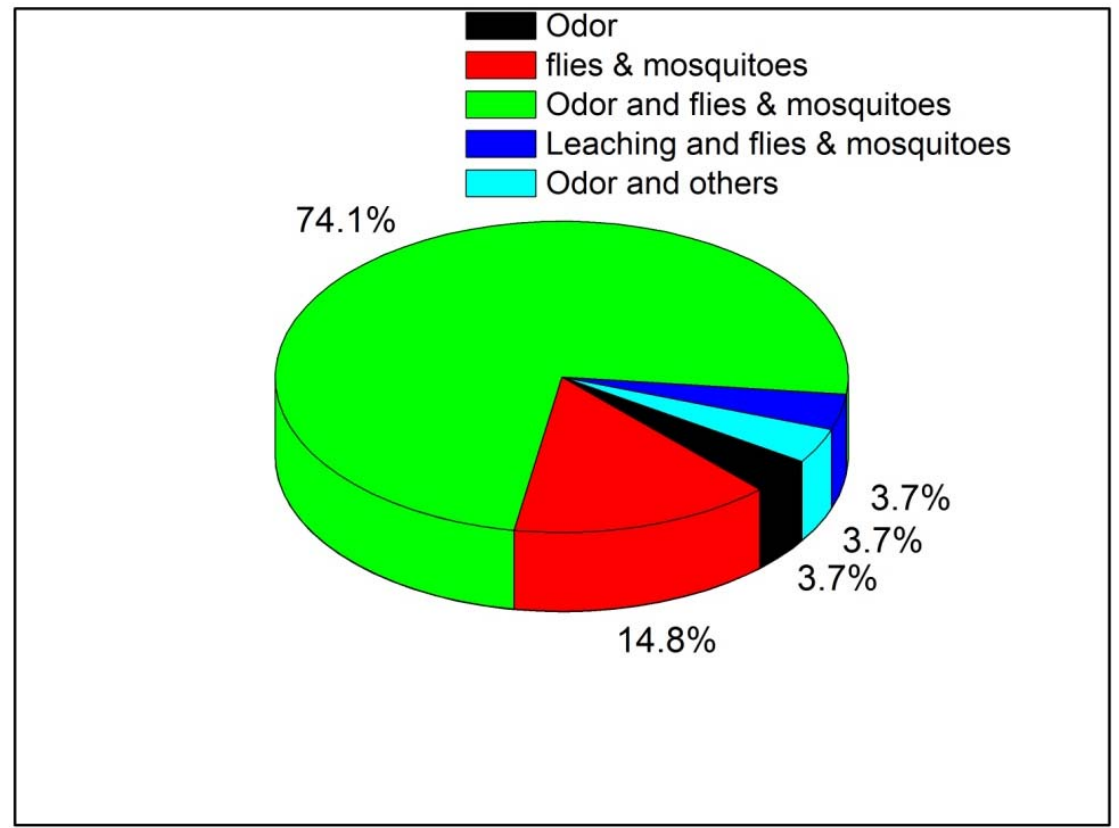

Figure 3. Types of environmental bad effects of poultry waste faced by farmer in the study area 


\section{Barriers of waste management}

The results of the present study indicated that 46 percent farmers were not concerned about proper disposal and environment friendly management of wastes and 16 percent considered waste management as unnecessary. About 24 percent encountered financial problem and the rest 14 percent had no comment (Fig. 4). Environmental negative impacts from poultry wastes could substantially reduce by using proper technologies but the problem is one of cost, corresponding incentives/disincentives and awareness (Gerber et al., 2007).

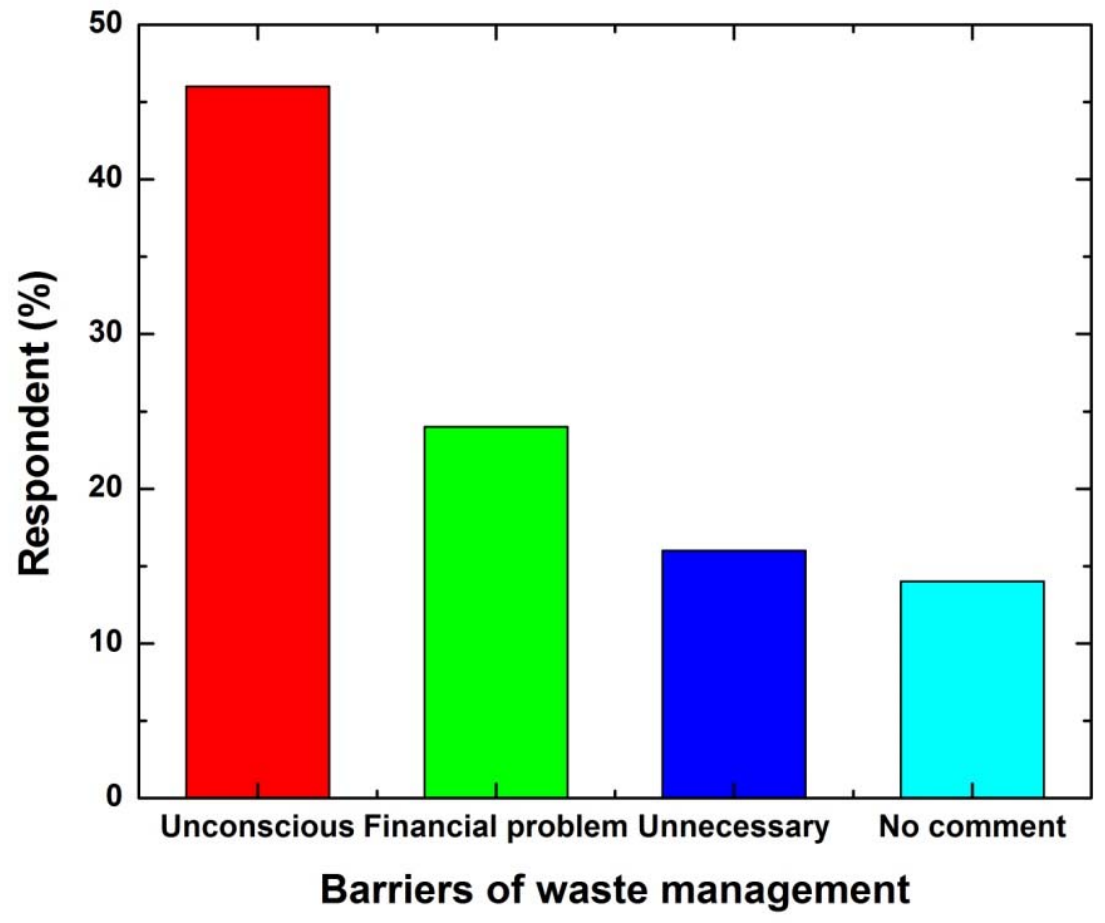

Figure 4. Barriers of poultry waste management in the study area

\section{CONCLUSION}

From the above finding, it can be concluded that the present system of litter management in the study area is neither satisfactory nor adequate. Farmers choose their litter based on availability rather than environmental and health concern. A great percent of poultry farmers have faced environmental and health problem related to waste. Unconsciousness is the major barrier of sound waste management therefore awareness building is one of the important approaches to address this issue. Environmental impacts of poultry production are not always confined to specific areas they also include impacts of global greenhouse gas emission related to energy use in animal production processes and manure management. A sustainable waste management system is a crying need to save our environment from pollution and greenhouse gas emission. Government, non-government, and community based organizations and community people should work together to make poultry farming environment friendly in our country. 


\section{REFERENCES}

1. Adeyemi OA and M Malomo, 2014. Survey of poultry wastes management in Abeokuta, Ogun state, Nigeria, 1: 14-19.

2. Akinbile CO, 2012. Environmental impact of landfill on groundwater quality and agricultural soils in Nigeria. Soil and Water Research, 7: 18-26.

3. Alabadan BA, PA Adeoye and EA Folorunso, 2009. Effect of different poultry wastes on physical, chemical and biological properties of soil. Caspian Journal of Environmental Science, 7: 31-35.

4. Amin MAA, MS Rahman, MAR Howlider, MM Ahmmed, 2009. Disposal of layer droppings reared in case and impact on environmental pollution. Journal of Bangladesh Agricultural University, 7: 281290.

5. Anosike V, 2007. Health Implications of Poultry Waste Utilization for Urban Agriculture: An Ecohealth Approach, 25-28.

6. Banglapedia 2013: Version 2013. Asiatic society of Bangladesh. Dhaka. Bangladesh.

7. Bhattacharya AN and JC Taylor, 1975. Recycling of animal waste as a feedstuff: A review. Journal of Animal Science, 1438: 1457.

8. Bowman A, K Mueller, and M Smith, 2000. Increased animal waste production from concentrated animal feeding operations: potential implications for public and environmental health. Occasional Paper Series, No, 2. Omaha, USA, Nebraska Centre for Rural Health Research.

9. Dahal BN, 1993. Poultry waste and its fate on environment. Journal of agricultural Science, 4: 35.

10. Dan LC, WR Casey and CM William, 2009. Best management practices for storing and applying poultry litter. The University of Georgia Cooperative Extension, 1-12.

11. Evans B and SH Woolf, 2013. The potential health impact of a poultry litter- to-energy facility in the Shenandoah Valley, Virginia. Center for Environmental studies Virginia Commonwealth University.

12. FAO, 2008. Poultry in the 21st century: avian influenza and beyond. Proceedings of the International Poultry Conference, Bangkok, 5-7 Nov. 2007, edited by O. Thieme and D. Pilling. FAO Animal Production and Health Proceedings No. 9. Rome.

13. Gerber P, C Opio, and H Steinfeld, 2007. Poultry production and the environment - a review. Animal Production and Health Division, Food and Agriculture Organization of the United Nations, Viale delle Terme di Caracalla, 00153 Rome, Italy, 23.

14. GoB 2010: Government of Bangladesh, Report of the task forces on Bangladesh development strategies of the 2010's. Univ. Press Ltd., Dhaka, Bangladesh, 2-4.

15. Griffiths N, 2004. Poultry litter: Best practice guidelines for using poultry litter on pastures. NSW Agriculture, 4: 212.

16. Hossain MM and MS Ali, 2009. Waste management in poultry farms and environmental protection in Bangladesh. In: Proceedings of the $6^{\text {th }}$ International Poultry Show and Seminar. The World Poultry Science Association, Bangladesh Branch, Dhaka, Bangladesh, 199-202.

17. ICDDRB 2004: Community health problem, a case study on cause of water borne diseases in rural area, 16.

18. Sarker BC, MA Alam, MM Rahman, AFMT Islam and MGF Chowdhury, 2009. Waste Management of Commercial Poultry Farms in Bangladesh. Journal of innovation and development strategy, 2: 34-37.

19. Waste concern, 2005. CDM Project potential in poultry waste management sector in Bangladesh. Dhaka, Bangladesh, 17-18. 